\title{
Assessing Effects of Capital Adequacy Ratio Requirements on Loan Demand of Kenya Commercial Bank Eldoret Town
}

\author{
Jackson Barngetuny \\ Address Correspondence to: \\ P.O.BOX 59699-00100, NAIROBI; KENYA
}

\begin{abstract}
Security of investors' reserve remains the significant worry of bank controllers. It is in this regard the capital sufficiency becomes significant and imperative. Capital adequacy is an origination that results from reworking the banks' current capital structure to rebuild the banking industry against the widespread establishment. This research's objective was to assess the effect of capital adequacy ratio requirements on the Bank of Kenya Commercial Bank's loan demand. The study adopted the Capital Buffer Theory. The study reviewed related literature to capital adequacy ratio requirements on the efficiency in the Bank. This study adopted an exploratory research design. The sample population of interest in this study consisted of all 23-bank employees of KCB, Referral Branch. The study adopted a census survey. The following research questions guided the interview. How effective would be capital adequacy ratio requirements on loan demand of Kenya Commercial Bank? The study used interview guides in the collection of data. Qualitative analysis was used to analyze the perception data collected from the key informants. Joint subjects were determined, and qualitative data, organizing, and discussing based on the main objective were done. These were presented using grouped data collected in the form of discussion. From the interviewed respondents, it was found that there might be significant impacts of capital adequacy ratio requirements on loan demand of $\mathrm{KCB}$. The elasticity of loan rate due to capital adequacy ratio requirement might affect loan demand, implying that there would be a change in loan demand for every percentage change in the loan rate. The study recommends that bank regulators be keen on the banks' capital adequacy ratio by laying down financial regulations on liquidity since financial regulation aims to enable banks to improve liquidity and solvency. Stricter regulation may be suitable for bank stability, but not for bank efficiency; restricting banks may lower bank efficiency and increase the probability of a banking crisis. There is a need for capital supplementation to keep up with Capital Adequacy Ratio (CAR) since stricter capital adequacy, robust supervision, and market discipline power promotes technical efficiency.
\end{abstract}

Keywords: Loan, Demand, Ratio, Capital, Bank

DOI: $10.7176 /$ RJFA/12-6-06

Publication date:March $31^{\text {st }} 2021$

\section{Introduction}

The banking institution is one of the most highly leveraged sectors of any economy. However, the ability to identify financial risk and take appropriate action is critical. In introducing prudential regulation as an integral part of Kenya's financial sector reforms, there have been arguments as to whether capital adequacy requirements are the best means to regulate the banking system (Mehta \& Bhavani 2017). Capital is critical to the perpetual continuity of a bank as a going concern. According to Wanjohi, Wanjohi, and Ndambiri (2017), Capital Market Authority introduced the internationally accepted Capital to Risk-Weighted Assets Ratio (CRAR), also called Capital Adequacy Ratio (CAR) system, as a Capital Adequacy measure can be achieved incrementally.

The important aspect of banking is the regulation of capital. Banking regulations are performed to assess a commercial banking center's growth by analyzing financial performance before adopting a new policy. That accomplishes a survey showing the progress and results of the demand for enacting the commercial banking sector. However, stringent regulations may result in adverse effects. However, regulations serve as prudential measures that mitigate economic crises' effects on a commercial institution's stability and subsequent accompanying macroeconomic results. Usually, international comparisons are made before implementing bank regulations. That enables policymakers to scrutinize different countries' results that can be contrasted due to their differing regulatory structures.

Similarly, more regulations may increase the cost of intermediation and reduce the profitability of the banking industry. Simultaneously, as banks become more constrained, their ability to expand credit and contribute to economic growth would be hampered (Taskinsoy, 2019). Financial performance is one of the concepts that need to be considered by bankers. Banking performance includes an overvaluation of the commercial Bank's financing over a short period. In Kenya, commercial banks have seen a shrinking growth in earnings, revenues, and assets. Kenya commercial banks' balance sheets have doubled. As far as assets are concerned, the rapid increase in junk bonds and the commercial paper market has given substantial institutions a high ground to access loans from the Bank. In terms of liability, new deregulation, privatization, and innovations have changed the customer's options. That compels individuals to deposit via a bank check account and pay through local bank branches. They use 
mutual funds that provide similar but valuable services. This paper assesses the effects of capital adequacy ratio requirements on loan demand at Kenya Commercial Bank to answer the question: How effective would be capital adequacy ratio requirements on loan demand of Kenya Commercial Bank? In the next section, the concept of capital adequacy requirements, then followed by measurement of Capital Adequacy Ratio, then Theoretical Framework, literature review, methodology, and finally findings are discussed.

\section{Conceptual/ Theoretical frameworks}

Undeniably, capital adequacy requirements underscore all banking activities and processes. As indicated by Kombo and Njuguna (2017) on Banking Supervision, there is three capital; actual, regulatory, and financial as takes after: - Actual capital alludes to the physical capital, which is represented by the balance report as value and long-term debt. It is measured as the proportion of value to add up to assets, otherwise called the capital ratio. Regulatory capital identifies with hazard-based capital, which the Bank keeps up following supervisory decided guidelines and is measured as the proportion of capital to risk-weighted resources; likewise alluded as a hazardbased capital ratio. A hazard-based capital rule suggests that the level of regulatory capital differs from the economy's condition and bank assets' hazard profile. Financial capital represents the extreme measure of capital that a bank requires to work its business successfully given its business strategies (Sakouvogui 2020).

For this journal article, the concept of measurement of capital adequacy ratio is fundamental. KCB performance is usually measured by calculating capital adequacy. Usually, it is initiated by ensuring that commercial banks meet the minimum statutory capital requirements. Regulation is presented as a minimum capital necessity imposed by the regulatory specialists Anwar and Murwaningsar (2017). Each Bank needs to meet the regulatory expert's minimum capital necessity, relying upon bank assets' qualities. The minimum level of bank capital relies typically upon the size of the Bank's loan book and hazard-based capital regime, identified with the hazard profile of bank assets. Regulatory capital proportions are a risk-weighted capital proportion with the Bank's capital in the numerator and the risk-weighted resources in the denominator: Financial performance is achieved by assessing credit risks and liquidity ratios. Commercial banks are consistent in their productivity by assessing investment ratios like asset returns, capital returns, and equity returns.

Capital Ratio $(\mathrm{CR})=$ Capital $(\mathrm{C}) /$ Risk Weighted Assets (RWA)

$=($ Capital $/$ Total Assets (A)) $/$ Risk-Weighted Assets (RWA)

$=$ level of capital or use/level of hazard

The Basel Committee has set standards in the Basel III framework that expects banks to hold $6 \%$ of Tier I capital (up from $4 \%$ in Basel II) of risk-weighted resources and $8 \%$ of Tier II total capital (8\% in Basel II) of riskweighted resources. Basel III likewise presented extra capital to enable national controllers to have up to another $2.5 \%$ of capital amid high credit development times.

The research problem is that investors' reserve remains the significant worry of bank controllers. It is in this regard the capital sufficiency becomes substantial and imperative. Capital adequacy is an origination that results from reworking the banks' current capital structure to rebuild the banking industry against the widespread establishment. Sufficient capital makes an opportunity for better standards in any business foundation. It goads business effort and incredible performance. The impact of capital adequacy on banks' performance cannot be thought little of since sufficient capital specifically and consequently impacts the measure of assets accessible for credits, which perpetually affects the level and degree of risk absorption. Despite its numerous parts and various capacities, bank capital is acting as a defensive pad against misfortunes accelerated by specific sorts of uncertainties. This view considers capital as a requirement to avoid default, and capital likewise acts as a pad to ensure investors and different banks against misfortunes at the working and liquidation stage.

The liberalization has brought in the inception of the competition in the Kenyan banking sector by weakening entry barriers and introducing differentiation after decades of financial repression. The blueprints of the reform were the Central Bank report published in 1996, followed by the banking sector reforms of 2014 (Muhindi \& Ngaba 2018). Despite the liberalization period coinciding with implementing the Basel norms elsewhere globally, the Kenyan Banking sector could not embrace these norms after decades of financial repression. The CMA report and the banking sector reforms report paved the way for the gradual implementation of new banking sector reforms. Among the few significant changes brought in by the reforms was implementing regulatory capital, which fosters a good measure for efficient capital allocation within the Bank (Kulane \& Kariuki, 2018).

In this era of holistic convergence, the weakening of entry barriers brought in the inception of the competition in the sector and technological advancements. It challenged the adaptive potential of the existing banks. Compliance with these norms and in the run for its existence in the competitive environment, the banks objectively incubated diverging portfolios of products and services, leading to a change in the banks' capital allocation and business operations (Berthilde, \& Rusibana 2020).

Research on the effect of capital prerequisite on loan demand in banks in Kenya has gotten little consideration despite fast development in this empirical throughout the years. This is somewhat tragic given the strength of the banking sector in the financial framework in Kenya. From the previous perspective, this research purposed to 
address this gap by assessing the empirical investigation of capital necessity and its effect on loan demand in Kenya's Kenya Commercial Bank. The main reason for the study is to assess the effectiveness of capital adequacy ratio requirements on the loan demand of Kenya Commercial Bank. The guiding question is How effective would be capital adequacy ratio requirements on loan demand of Kenya Commercial Bank?

Following the capital buffer theory (Marcus 1984, Milne and Whalley 2001), banks go for holding more capital than required (i.e., keeping up regulatory capital over the regulatory minimum) as protection against breach of the regulatory minimum capital necessity. The capital buffer theory expresses that banks adjust expenses and benefits over the whole balance sheet when subjected to capital regulation. Essentially, the capital level ought to be set as an endogenous reaction to risks and challenges in connection with the breach of the regulatory minimum, the cost of capital surpluses, and the costs and time constraints for adjusting capital levels. The capital buffer is the overabundance capital a bank holds over the minimum capital required. The capital buffer theory embroils that banks with low capital buffers endeavor to reconstruct an appropriate capital buffer by raising capital, and banks with high capital buffers endeavor to keep up their capital buffer. More capital tends to absorb unfriendly shocks and, in this way, decreases the probability of failure. Thus, portfolio hazards and regulatory capital are thought to be positively related. Banks raise capital when portfolio hazard goes up with a specific end goal to keep up their capital buffer.

Milne and Whalley (2001) demonstrate the dynamics in a bank's capital decision as a continuous-time inventory issue. The administrator must choose at what level he should issue new capital or hold up until the supervisory authority powers him to do so. Besides balancing the expenses and benefits of the capital overflow, the key purpose of the model is that banks with high charter value would have more to lose if they breach the regulation. Hence, they have a more prominent motivating force to keep up additional capital. The models have essential ramifications for the effect of capital control on banks' hazard taking. As per the authors, for the time being, banks' incentive to go for risks decreases as their capital levels approach the regulatory minimum.

The economic efficiency concept is derived from the neoclassical microeconomic approach, which relies on resource utilization and allocation. The concept delves into the non-wastages of these resources by focusing on cost reduction and realizing the maximum output level for a certain innovation and inputs. Economic efficiency is boosted by value creation. In that way, an organization is regarded as economically efficient when it has a competitive edge over competing firms that performs poorly in the same field. That makes efficient change a critical concept in transforming these inputs into a credible output value. For these reasons, the efficient change increases the value and decreases the same value when there is insufficient change. Also, efficiency is used for policy intervention to assess the value of policy options.

Profit maximization explains economic efficiency in broader terms and is linked to perfectly competitive markets. Efficiency gains may accrue in a competitive industry for firms that reap normal profits in the long-run. Besides, efficiency gains accrued while responding to changes in customer's preferences are achieved by increasing the outputs. Regardless of selling the output at lower, higher, and same price, it would rely on the long-run cost curves position. Therefore, efficiency depends on welfare improvements.

In the era of measurements, Bankers may explore various factors to explain a firm's efficiency levels. Significantly, other factors can be inherent in the firm's internal organizational structure. Some of these factors capture crucial features like workers' skills levels, experience, and expertise. Internal sources usually entail production technology disruption, human mistakes, laxity, and inadequate resources to respond to incentives changes in terms of efficiency. The firm's external factors may include market structure, labor disputes, strikes, business cycles, macro-economic shocks, and regulatory constraints. When taken into consideration, these factors contribute to huge differences and variability across organization output levels.

Internal factors are specific, rendering the environmental factors to be outside of control. Therefore, investors should be careful to exercise the firm's efficiency by differentiating between external and internal factors.

\section{Data and methods}

The Capital Adequacy Ratio sets standards for banks by looking at a bank's ability to pay liabilities and respond to credit risks and operational risks. The authorization of capital necessities can connect a bank's capital position with its loaning nearly as a component of a bank's procedure meeting regulatory standards. For instance, if bank equity is not perfectly elastic, a bank with too minimal capital could enhance its capital position by reducing its size. One approach to do that is to decrease loans. Dagher et al. (2020) find that in the 1990s, banks' insufficient capital adjusted their capital positions to some degree by developing more gradually than different banks. More generally, banks with more substantial capital positions can expand loans and still meet regulatory capital standards. According to Calomiris and Chen (2020), the alternatives model of the deposit ensure additionally proposes another regulatory reason for connecting leverage and the growth of risky assets, for example, loans. The estimation of the deposit protection ensures it is emphatically identified with the level of benefit or non-leverage risk of a bank. This suggests that regulatory policy that considers the protection framework's liability can be relied upon to stretch out effort to control non-leverage risk. 
Celerier, Kick, and Ongena (2019) give experimental proof of collective energies between duty loaning and stores, steady with their model. However, they did not test the impact of bank capital on liquidity creation. Celerier, Kick, and Ongena (2019) found that banks have a similar preferred standpoint in supporting liquidity hazard in the economy since banks encounter deposit inflows following a market emergency or liquidity stun that enable them to have more subsidizes to give the extra credits drawn down under responsibilities at such circumstances. These investigations do not concentrate on the part of bank capital, and they do not look at the impact of bank capital on credit responsibilities. Nonetheless, they incorporate the capital proportions in relapses of some liquidity classes, yielding uncertain expectations identified with the effect of capital on liquidity creation.

Micro-prudential and macro-prudential theorists suggest a meaningful relationship between employee productivity and regulation in each financial institution. The two approaches support urges enforcement of bank regulation irrespective of the shrinkage that may trigger a bank asset and obtain new capital from stock markets. Both theories seek to achieve financial stability by safeguarding the welfare of taxpayers. The effect of this action will reduce the economic output of commercial banks. Regulation of commercial banks strengthens the functions of the private banking markets. At macro-economic levels, the study has shown that the minimum wage can decrease commercial banks entering the market. On the flip side, commercial banks' increased productivity will rise, leading to an increase in overall wealth creation. If the commercial bank survives, the cost of wages will increase without an influence on employment. Minimum wage growth opens different avenues for a more fruitful commercial bank to substitute those organizational senses that, in turn, push for an emerging business to improve its profitability. As this minimum wage directly impacts every low-income family, the commercial Bank tends to benefit them compared to a highly paid corporate society. Low-wage workers are nearly driven out of business due to higher government regulations on banking institutions based on the lending risks to lower-income levels comparable to the rich.

Another primary consideration that contributes to deciding the CAR for the banks is funds deposited by the Bank's customers Taiwo et al., (2017). Deposits are a cheap source of the fund compared to the external source of finance, for example, securities, credits from business angles and through syndications. Consequently, the reduction in deposit patterns will influence the increase in the cost of obtaining through external sources; increment in option borrowing cost will decrease the banks' profit margin, more financial will be required to repay the deficiency in profitability. Deposits incorporate demand deposits and term deposits. They demonstrate the share of deposits contrasted with add up to assets.; the percentage of deposits in non-liabilities is considered a factor in board regression analysis. The stringent CAR requirements push banks to apply stricter acceptance procedures to issue new loans. Bank efficiency levels more likely to assess risk and capital. For example, authorities sometimes enable efficient commercial banks with higher flexibility based on overall risk profile and capital leverage. Less efficient banks with less capital are more likely to pursue a greater risk to compensate for the loss of returns associated with moral hazards.

This journal paper is guided by the following research question: How effective would be capital adequacy ratio requirements on loan demand of Kenya Commercial Bank?

\section{Methodology}

This Paper was exploratory and textual in nature and used a qualitative approach. The sample population of this study consisted of all 23-bank employees of KCB. The study will adopt a census survey, which was deemed ideal for this study because the discussions with respondents provide a deeper understanding of processes and feelings (Rahi, 2017). Data collection was included interviews and literature.

\section{Data Analysis}

The study found out that the loan rate elasticity due to capital adequacy ratio requirement might affect loan demand from the interviewed respondents, which suggests a change in loan rate will change demand. According to the Basel III system, higher capital requirements would increase banks' minimal cost of credits when the nominal cost of capital is higher than the peripheral cost of stores. In such a case, higher cost of value financing contrasted with obligation financing would drive the Bank to raise the rates on their loaning. An immense amount of value lessens the Bank's peril yet brings about a decrease consequently on value.

Additionally, the study found out that an increase in capital requirements reduces loan increases; thus, The Bank should need to expand the capital rate, and such an expansion would tend to lessen the advance rate prompting a reduction of the regular obtaining rate. These requirements must be met inside a drawn-out period, and this showed the impacts would not be too discernible.

The study also found out that when the Bank has higher loan loss reserves, it will also tend to have higher capital levels. Hence, it demonstrates that to be a cost-effective Bank seems to suggest the existence of opposite relationship exists amongst capital and hazard; potentially directions permit more cost-productive banks to exchange off capital and hazard taking, contrasted and wasteful banks. It may be the case that capital confinements are less official for more productive banks, so they have more prominent adaptability in exchanging capital and 
hazard. This alternative is less accessible to inefficient operators.

\section{Discussion of Findings}

From the interviewed respondents, the study found out that the elasticity of loan rate due to capital adequacy ratio requirement might affect loan demand, implying that for every percentage change in loan rate, there would be a change in loan demand as needs be, the effect of increment in a loan on the loan demands in the perspective of the increase in capital requirements because of the execution of Basel III in the Kenyan setting. According to the Basel III system, higher capital requirements would bring about increment in banks' minimal cost of credits when the minor cost of capital is higher than the peripheral cost of stores. In such a case, higher cost of value financing contrasted with obligation financing would drive the Bank to raise the rates on their loaning. A larger amount of value lessens the peril of the Bank yet brings about a decrease consequently on value). From the findings, there is a significant relationship between commercial banks' financial performance and prudential regulations across Kenya and foreign countries. Thus, the concept holds that commercial banks' performance in Kenya varies from one area to another depending on the operating environment and other micro and macro-economic factors. Such ideas support that Kenya still lacks adequate studies to determine the extent to which the commercial's financial performance is determined. Other studies also reveal the negative or weak relationship between economic performance and regulation of commercial banks.

Also, these findings, moral hazards are experienced when supervisory agencies, governments, and prompt bank agents to accept that they shall be engaged in safeguarding firms and their creditors when a failure occurs. As predicted by moral hazard theory, if capital requirements push the Bank to raise its capital, they react by increasing its profit. Typically, capital adequacy denotes commercial banks' measurement in terms of strength and ability to determine financial theory options. CAR gauges the capacity of commercial banks to adapt liquidation and risk adequately. Commercial banks establish capital adequacy by evaluating CAR, which assesses the main capital of the Bank. CAR obtained is usually expressed in percentage based on its weighted risk resources. A commercial bank capital includes one level, level two of capital, and capital that absorbs losses. Besides, commercial bank assets have different risk weighing due to varied risk profiles. That enables CAR to adjust for non-risky assets by allowing commercial banks to curb lower-risk assets. Nevertheless, CAR continues to be empirically inconclusive.

\section{Conclusions}

Lastly, the study concluded that the elasticity of loan rate due to capital adequacy ratio requirement might affect loan demand, suggesting that there would be a corresponding change in loan demand for every percentage change in the loan rate.

The capital requirement in Kenyan commercial affects commercial banks' behavior. That is because Kenya's banking sector has recently pursued a robust policy and structural changes geared towards enhancing banking industry performance. Such changes include financial innovation, supervision, and prudential regulation. The ultimate economic law is to allow banks to improve solvency and liquidity.

Implementing new rules and standards shall make the banking sector support sustained economic growth and protect long-term credit supply credit. In that way, strict regulation is effective and better for bank stability. These regulations indicate that banks and policymakers handle trade-offs between financial efficiency and stability. That calls for a need to evaluate CAR's impact on commercial bank efficiency.

\section{Reference}

Anwar, J., \& Murwaningsar, E. (2017). The effect of credit risk and capital adequacy ratio upon return on asset (a case study at banking listed in Indonesia Stock Exchange). The Accounting Journal of Binaniaga, 2(02).

Asiamah, N., Mensah, H. K., \& Oteng-Abayie, E. F. (2017). General, target, and accessible population: Demystifying the concepts for effective sampling. The Qualitative Report, 22(6), 1607.

Berthilde, M., \& Rusibana, C. (2020). Financial Statement Analysis and Investment Decision Making in Commercial Banks: A Case of Bank of Kigali, Rwanda. Journal of Financial Risk Management, 9(04), 355.

Calomiris, C. W., \& Chen, S. (2020). The spread of deposit insurance and the global rise in bank asset risk since the 1970s. Journal of Financial Intermediation, 100881.

Celerier, C., Kick, T. K., \& Ongena, S. (2019). Taxing Bank Leverage: The Effects on Bank Portfolio Allocation. Available at SSRN 2829326.

Dagher, J., Dell'Ariccia, G., Laeven, L., Ratnovski, M. L., \& Tong, M. H. (2020). Bank Capital: A Seawall Approach. 62nd issue (March 2020) of the International Journal of Central Banking.

Dahabreh, I. J., \& Hernán, M. A. (2019). Extending inferences from a randomized trial to a target population. European Journal of Epidemiology, 34(8), 719-722.

Kombo, K., \& Njuguna, A. (2017). Importance of capital adequacy requirements in Basel III framework for commercial banks in Kenya. 
Kulane, A. A., \& Kariuki, S. N. (2018). The influence of board structure on the financial performance of tier three commercial banks in Nakuru County, Kenya. INTERNATIONAL JOURNAL OF BUSINESS AND PROCESSES (ISSN 2616-3209), 4(2), 6-6.

Marcus, A. J. (1984). Deregulation and bank financial policy. Journal of banking \& finance, 8(4), 557-565.

Mehta, A., \& Bhavani, G. (2017). What Determines Banks' Profitability? Evidence from Emerging Markets-the Case of the UAE Banking Sector. Accounting and Finance Research, 6(1), 77-88.

Milne, A., \& Whalley, A. E. (2001). Bank capital regulation and incentives for risk-taking. Cass Business School Research Paper.

Mohajan, H. K. (2017). Two criteria for good measurements in research: Validity and reliability. Annals of Spiru Haret University. Economic Series, 17(4), 59-82.

Muhindi.K.A \& Ngaha. D. (2018). Effect of Firm size on financial performance on banks: Case of Commercial banks in Kenya. International Academic Journal of Economics and Finance, 3(1)175-190

Rahi, S. (2017). Research design and methods: A systematic review of research paradigms, sampling issues, and instruments development. International Journal of Economics \& Management Sciences, 6(2), 1-5.

Sakouvogui, K. (2020). Out-of-sample Predictability of Economic Efficiency Measures of US Banks: Evidence of capital adequacy requirements.

Schoonenboom, J., \& Johnson, R. B. (2017). How to construct a mixed methods research design. KZfSS Kölner Zeitschrift für Soziologie und Sozialpsychologie, 69(2), 107-131.

Taiwo, J. N., Ucheaga, E. G., Achugamonu, B. U., Adetiloye, K., Okoye, O., \& Agwu, P. E. (2017). Credit risk management: Implications on bank performance and lending growth. Saudi Journal of Business and Management Studies, 2, 584-590.

Taskinsoy, J. (2019). Higher Capital and Liquidity Regulations of Basel Standards Have Made Banks and Banking Systems Become More Prone to Financial and Economic Crises. Available at SSRN 3401378.

Wanjohi, S. M., Wanjohi, J. G., \& Ndambiri, J. M. (2017). The effect of financial risk management on the financial performance of commercial banks in Kenya. International Journal of Finance and Banking Research, 3(5), 70-81. 